\title{
Reassessing the taxonomic diversity of Plagiothecium section Orthophyllum in the North American bryoflora
}

\author{
GRZEGORZ J. WOLSKI
}

Department of Geobotany and Plant Ecology, Faculty of Biology and Environmental Protection, University of Lodz, 12/16 Banacha St., 90-237, Lodz, Poland; e-mail: grzegorz.wolski@biol.uni.lodz.pl

\begin{abstract}
At the beginning of the twentieth century, Plagiothecium nemorale s.l. and $P$. succulentum, both belonging to $P$. sect. Orthophyllum, were considered to be distributed across almost the entire Northern Hemisphere. However, in the mid-twentieth century these taxa were recircumscribed resulting in their exclusion from the North American bryoflora and restricting their distributions to Asia and Europe, and in the case of Plagiothecium nemorale s.l., also North Africa. More recently, it was found that $P$. nemorale s.l. is a taxonomic complex comprising three distinct species: $P$. nemorale s.s., $P$. longisetum, and $P$. angusticellum. I revised the North American material of $P$. section Orthophyllum deposited in three herbaria $(\mathrm{NY}, \mathrm{FH}, \mathrm{F})$ and found that five examined taxa of the section are present in the North America. Two of the species $P$. angusticellum and $P$. longisetum, have not been recorded from North America previously, while two others, $P$. nemorale and P. succulentum, had not been listed in the North American bryoflora for 50 years. One taxon is new for the U.S.A. - P. succulentum f. propaguliferum. Here I provide detailed descriptions of the anatomical and morphological features of the recorded taxa along with photographic documentation of their most important characteristics. I also summarize their known distributions in North America and ecological preferences and provide a key for their identification.
\end{abstract}

Keywords: Taxonomic revision, $P$. nemorale, $P$. longisetum, P. angusticellum, P. succulentum.

As science has developed, so has the range of the family Plagiotheciaceae M.Fleisch, as earlier morphological and anatomical studies (Brotherus, 1909; Fleischer, 1912; Jedlička, 1948; Iwatsuki, 1970; Lewinsky, 1974; Buck \& Ireland, 1989) have been supplemented by more modern ones based on molecular research (Pedersen \& Hedenäs, 2001, 2002; Wynns \& Lange, 2014; Wynns et al., 2017; Wynns \& Schröck, 2018; Ignatova et al., 2019; Wolski, NowickaKrawczyk, 2020). One of the genera belonging to this family is Plagiothecium Schimp., globally distributed pleurocarpous mosses which are especially widespread in the temperate zone and the tropics (Dierßen, 2001; Ochyra et al., 2008; Wynns, 2015).

Jedlička (1948) erected P. sect. Orthophyllum Jedl. in his Monographia Specierum Europaearu, gen. Plagiothecium s. s., within which he included three species: P. Roeseanum (Hampe) Bryol. Eur. [synonym of $P$. cavifolium (Brid.) Z.Iwats.],
P. succulentum (Wilson) Lindb., and P. neglectum Mönk. [synonym of P. nemorale (Mitt.) A.Jaeger]. More recently, Wynns (2015) recognized six species in section Orthophyllum: P. cavifolium, $P$. cochleatum Dixon, P. japonicum Sakurai, P. nemorale, P. rhizophyllum Sakurai, and $P$. succulentum. New research on $P$. nemorale s.l. (Wolski, Nowicka-Krawczyk, 2020) resulted in the restoration of one of it synonyms $P$. longisetum Lindb., and the description of a new species, P. angusticellum G. J. Wolski \& P. Nowicka-Krawczyk; both are properly placed in section Orthophyllum.

In the nineteenth century, Plagiothecium sylvaticum (Brid.) Bruch \& Schimp. was included in the North American bryoflora, it being the only species recorded from North America at the time that is now considered to be a synonym of P. nemorale (Sullivant \& Lesquerux, 1865; Macoun \& Kindberg, 1892; Renauld \& Cardot, 1892; Macoun, 1889). Although studies of the 
North American bryoflora increased in the twentieth century (e.g., Andrews, 1921; Thomas, 1952; Ireland et al., 1987; Anderson et al., 1997), records of Plagiothecium were relatively rare and few additional taxa of the genus were recorded from the area. Species which are now considered to be synonyms of $P$. nemorale and $P$. succulentum were recorded only extremely rarely and mainly in studies from the first half of the twentieth century (Grout, 1939; Sharp, 1939; Gier, 1949; Clebsch, 1954; Githens, 1957; Norris, 1967).

Trends in the taxonomic history of Plagiothecium in North America are well illustrated by analysis of the bryophyte lists for the continent. Grout $(1932,1940)$ recognized 31-32 taxa of Plagiothecium in North America, including $P$. sylvaticum and $P$. sylvaticum var. succulentum (Wilson) Husnot. Over time, many of these taxa were transferred to other genera, leaving only 13 taxa of Plagiothecium (including $P$. sylvaticum and P. succulentum) in North America in the list of Crum et al. (1965) and subsequently supported by the research of Worley and Iwatsuki (1970).

Undoubtedly the most influential works on North American Plagiothecium were Ireland's $(1969,1985,1986)$ taxonomic revisions, in which he recognized only six to eight species of Plagiothecium in the North American bryoflora. In those works, he synonymized several taxa, mainly within $P$. cavifolium, and excluded from North America others, including $P$. sylvaticum, $P$. neglectum, $P$. nemorale, and $P$. succulentum. The distributions of these last two taxa, previously considered to range across the whole Northern Hemisphere, were thus restricted to Asia and Europe, and in the case of $P$. nemorale s.l. also northern Africa (Hill et al., 2006; Ignatov et al., 2006; Ros et al., 2013; Suzuki, 2016).

Ireland's taxonomic concepts were largely followed in subsequent bryological lists for this part of the world. For example, Crum et al. (1973) listed only seven taxa of Plagiothecium in their next list for North America, which was then followed by Anderson et al. (1990). In a worldwide revision of the Plagiothecium, Wynns (2015) added a number of taxa of the genus to the North American bryoflora, but continued to exclude $P$. nemorale and $P$. succulentum.

My revision of North American material of Plagiothecium sect. Orthophyllum suggests that recent treatments underestimated the taxonomic diversity of the group in North America and brings into question the widespread adoption of Ireland's taxonomic concepts. This article presents the results of this research.

\section{Materials and methods}

Nine-hundred specimens of Plagiothecium sect. Orthophyllum from three North American herbaria (NY, FH, F) were reviewed. All of them from these collections were studied more closely and qualitative and quantitative characteristics of their gametophytes were measured. Characters examined included - qualitative features related to the stem leaves: such as leaf shrinkage, symmetry, shape and concavity, the curvature and serrations of the leaf apex, the shape of leaf cells, the shape of decurrent cells, and the formation, or not, of distinct auricles by these cells, and quantitative features (length and width) of the abovementioned structures. The resulting data were used to make species descriptions and to direct photographic imaging. Taxon distributions and ecological preferences were summarized from specimen label data. The taxon descriptions are based exclusively on specimens originating in North America. All examined specimens are listed in Appendix 1. The names of individual taxa were adopted from Wynns (2015), with the exception of the $P$. nemorale complex (Wolski, Nowicka-Krawczyk, 2020).

\section{Results}

The revision indicated that in North America there are two species that have been excluded since the widespread adoption of Ireland's (1969) classification and have not subsequently been recorded for the continent: $P$. nemorale and $P$. succulentum. In addition, a form of the second species has been found - P. succulentum $\mathrm{f}$. propaguliferum $\mathrm{E}$. Bauer, and this taxon is listed for the first time in the U.S.A. area. Also, the revision indicates one species that until now was considered a synonym but now is treated as separate $-P$. longisetum, and one new for North America - P. angusticellum. The analysis of herbarium materials indicates that those species in the past years were most often wrongly determined as $P$. cavifolium and $P$. denticulatum (Hedw.) Schimp. 
TAXONOMIC TREATMENT

Plagiothecium nemorale (Mitt.) A.Jaeger, Bericht über die Thätigkeit der St. Gallischen Naturwissenschaftlichen Gesellschaft 18761877: 451. 1878. Stereodon nemoralis Mitt., Journal of the Proceedings of the Linnean Society, Botany, Supplement 1: 104. 1859. Plagiothecium silvaticum var. nemorale (Mitt.) Par., Index Bryologicus 967. 1898. Type: [India] In Himalayae orient. reg. temp., Sikkim, in monte Tonglo (ad radicem filicis cujusdam), s.d., J. D. Hooker s.n. (NY 913349!).

Plagiothecium sylvaticum sensu Schimp., non Brid., Bryologia Europaea 5: 192. 503, fasc. 48 Monogr. 14. 11. 1851.

Plagiothecium neglectum Mönkm. Die Laubmoose Europas. 866. 1927. Type: sine loco, sine dato, sine coll. s.n.

Plagiothecium saxicola Sak., Botanical Magazine, Tokyo 48: 395. 1934. Type: [Japan], Hondo, Prov. Aki, Mt. Fuku ji, ad saxas, 4 Jan 1933, Y. Doi Typus in Herb. K. Sakurai 3282 (MAK3282, PC 132573!).

Plagiothecium silvaticum var. latifolium Cardot, Bulletin de la Société Botaniquw de Genéve sér. 2, 4: 385. 1912. Type: [Japan], Iyo (Gono) s.d. (original material: n.v.); Corée: île Quelpaert, sine dato, Faurie 507 (treated as an isosyntype by Iwatsuki (1970): KYO507).

Plagiothecium silvaticum var. rhynchostegioides Cardot, Bulletin de la Société Botaniquw de Genéve sér. 2, 4: 385. 1912. Type: [Japan]: Mororan, bas-fonds, sur pierres, Cardot 2965 (treated as an isotype by Iwatsuki (1970): KYO2965).

Plants medium-sized, dark green, dull, without metallic luster. Stems to $1.5 \mathrm{~cm}$ long, complanate-foliate, in cross-section rounded, with a diameter of 350-450 $\mu \mathrm{m}$, central strand developed, epidermal cells $7.5-17.5 \times 12.5-$ $25 \mu \mathrm{m}$, parenchyma thin-walled, $20-50 \times 30$ $50 \mu \mathrm{m}$; leaves spreading, in dry condition shrunken, concave, symmetrical, ovate (Fig. 1), those from the middle of the stem $0.1-1.5 \mathrm{~mm}$ long, $0.9-1 \mathrm{~mm}$ wide measured at the widest point; those near the top of the stem much smaller; the apex straight, acuminate, apiculate and denticulate; costae 2 , very rarely 1 or 3 , extending to half of leaf length, reaching $0.40-0.60 \mathrm{~mm}$; laminal cells in transverse rows, narrowly hexagonal toward the apex and midleaf, and elongate-hexagonal toward the insertion, the length and width variable depending on location: $40-70 \times 15-20 \mu \mathrm{m}$ at apex, 50$90 \times 17-20 \mu \mathrm{m}$ at mid-leaf, and 100-140 $\times$ 17-20 $\mu \mathrm{m}$ at lower part of leaf (Fig. 1); decurrencies of three rows of rectangular cells, 37.5-87.5 × 15-20 $\mu \mathrm{m}$. Sporophytes unknown in North America.

Distribution and habitat.-Specimens of Plagiothecium nemorale in North America have been seen only in eastern North America. This species is recorded from Canada (Nova Scotia) and the U.S.A. (Maine, New York, and North Carolina) (Fig. 6). In these localities, it grows in epigeic (along the trail), epilithic (in deciduous forests on shady rocks), and epiphytic habitats (on the moist base of a tree in a Fagus forest; see Appendix 1).

Plagiothecium longisetum Lindb., Acta Societatis Scientiarum Fennicae 10: 232. 1875. Type: [Japan]. ad Nikosan ins. Kiusiu, fertile, 16 Junii $1863, S$. O. Lindberg (PC0132572!, H-SOL 1563011 !). Plagiothecium longisetum var. brevinerve Ihsiba, Transactions of the Sapporo Natural History Society 13: 396. 1934. Type: [Japan]. Mt. Hakk da, Mutsu, 1933, S. Murai s.n.

Large plants, yellowish green, without metallic luster. Stems to $2.5-3 \mathrm{~cm}$ long, complanatefoliate, in cross-section rounded, with a diameter of $230-300 \mu \mathrm{m}$, central strand developed, epidermal cells $20-25 \times 17.5-25 \mu \mathrm{m}$, parenchyma thin-walled, 20-27.5 × 15-30 $\mu \mathrm{m}$; leaves concave, strongly asymmetrical, ovate (Fig. 2), spreading, in dry condition shrunken, those from the middle of the stem 1.8-2.6 mm long, $1.4-1.5 \mathrm{~mm}$ wide measured at the widest point; those near the top of the stem much smaller; the apex straight, not denticulate, acute to apiculate; costae 2, extending to half of leaf length or more, reaching $0.80-1 \mathrm{~mm}$; elongate-hexagonal cells in irregular transverse rows, areolation very lax; the length and width variable depending on location: $62-112 \times 17-20 \mu \mathrm{m}$ at apex, $100-130 \times 17-$ $20 \mu \mathrm{m}$ at mid-leaf, and $100-150 \times 20-23 \mu \mathrm{m}$ at lower part of leaf (Fig. 2); decurrencies of 3 rows of rectangular cells, 45-62.5 × 15-25 $\mu \mathrm{m}$. Sporophytes unknown in North America.

Distribution and habitat.-Specimens of Plagiothecium longisetum in North America have been seen in eastern North America and the Pacific Northwest. This species is recorded from Canada (British Columbia) and the U.S.A. (Pennsylvania, Virginia) (Fig. 6). In these localities, it grows mainly in epigeic (seepy humus, on the floor of Rubus spectabilis thicket) and epilithic 


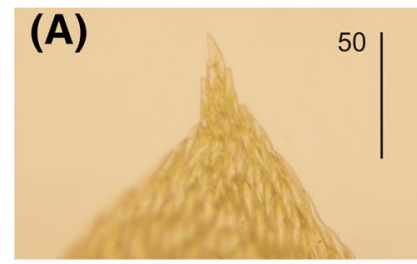

(E)
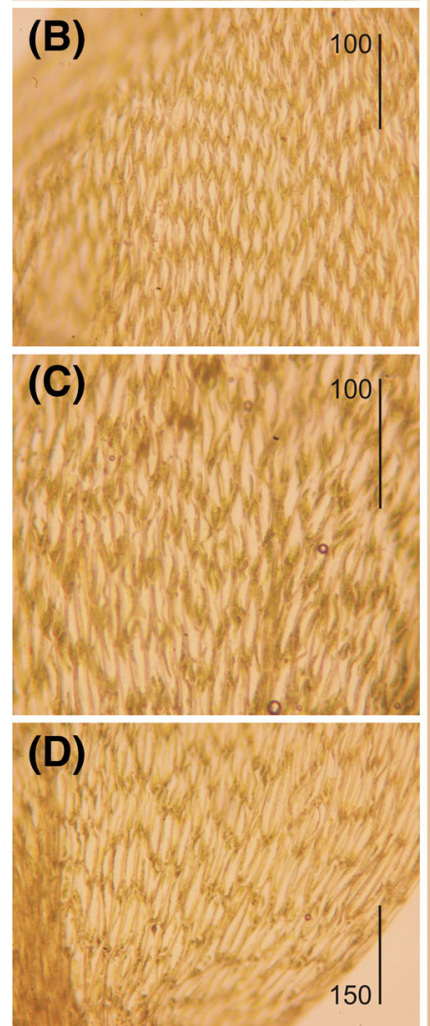

Fig. 1. Plagiothecium nemorale specimens from North America (from R. Düll 855, NY 00506577). A. Leaf apex. B-D. Cells exhibiting shape and dimensions from three different leaf zones. B. Distal zone, C. Mid zone, D. Basal zone. E. Stem leaf of the examined species. (Scales in $\mu \mathrm{m}$.)

habitats (on shady rocks, on moist shaded sandstone, on boulders in shade; see Appendix 1).

Plagiothecium angusticellum G. J. Wolski \& P. Nowicka-Krawczyk, PLOS ONE 15(3): e0230237. 2020. Type: Poland. Łódzkie Voivodeship, Grądy nad Moszczenicą reserve, $51^{\circ} 55^{\prime} \mathrm{N}, 19^{\circ} 29^{\prime} \mathrm{E}$, at the base of Carpinus betulus in Fraxino-Alnetum forest, 11 Dec 2017, G. J. Wolski (holotype: LOD 14927!; isotype: LOD 14937!).

Plants medium-sized, light green, without metallic luster. Stems to $1.5 \mathrm{~cm}$ long, complanatefoliate, in cross-section rounded, with a diameter of 250-300 $\mu \mathrm{m}$, central strand developed, epidermal cells $7.5-12 \times 15-25.5 \mu \mathrm{m}$, parenchyma thinwalled, 15-37.5 × 17.5-26 $\mu \mathrm{m}$; leaves spreading, in dry condition not shrunken, ovate, concave, asymmetrical (Fig. 3), those from the middle of the stem $1-1.7 \mathrm{~mm}$ long, $0.6-1 \mathrm{~mm}$ wide measured at the widest point; those near the top of the stem much smaller; the apex acuminate, slightly curved, not denticulate; costae 2, short, not extending to half of leaf length, reaching 0.4$0.75 \mathrm{~mm}$; laminal cells narrowly elongate-hexagonal, gently asymmetric, in irregular transverse rows, the length and width variable depending on location: $75-100 \times 12.5-17.5 \mu \mathrm{m}$ at apex, $110-120 \times 12.5-17.5 \mu \mathrm{m}$ at mid-leaf, and 90- 

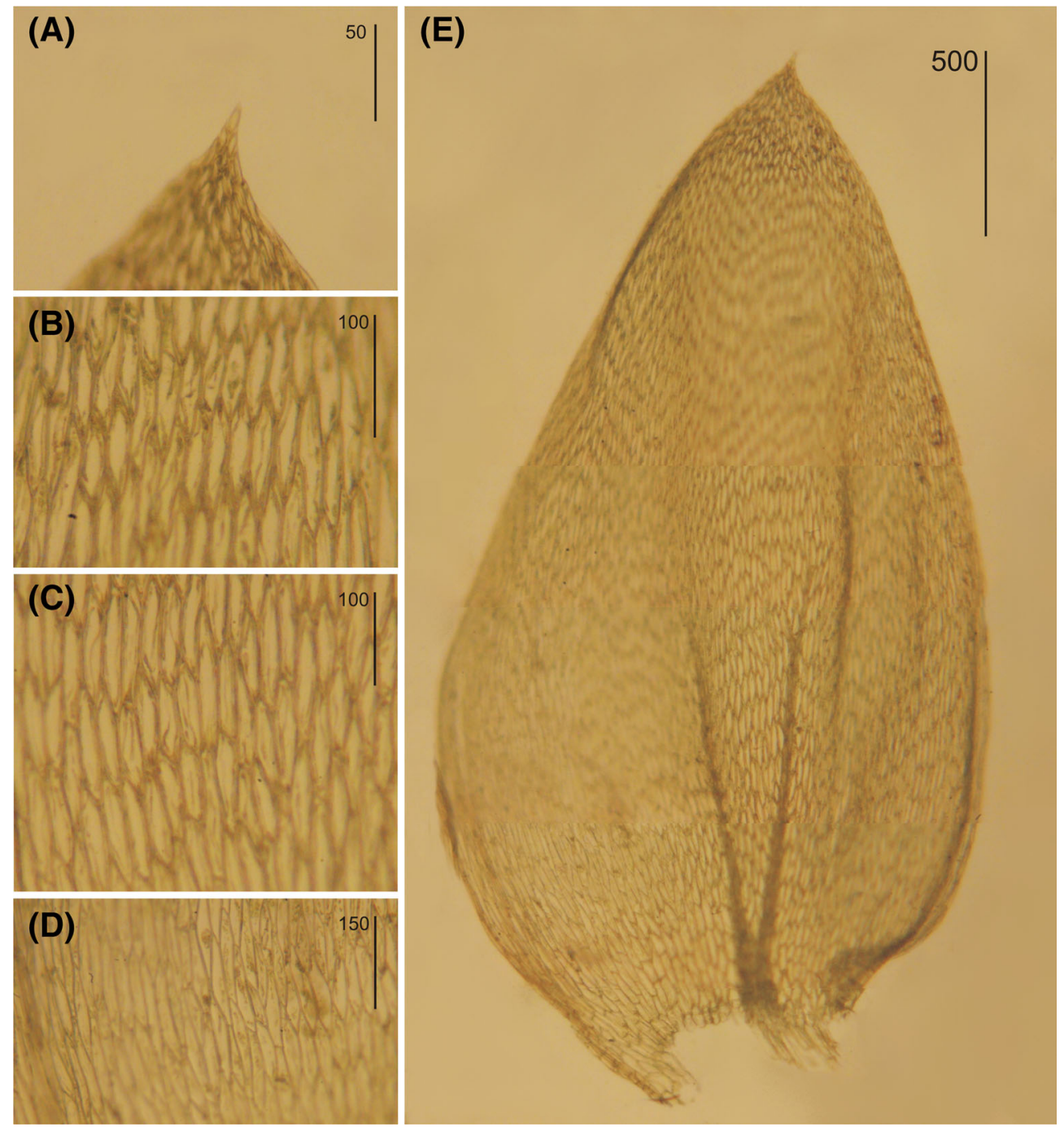

Fig. 2. Plagiothecium longisetum specimens from North America (from W. B. Schofield 31,629, NY 00163472). A. Leaf apex. B-D. Cells exhibiting shape and dimensions from three different leaf zones. B. Distal zone. C. Mid zone. D. Basal zone. E. Stem leaf of the examined species. (Scale in $\mu \mathrm{m}$.)

$137.5 \times 17.5-20 \mu \mathrm{m}$ at lower part of leaf (Fig. 3); decurrencies of 2 rows of rectangular to quadrate cells, 45-87.5 × 10-17.5 $\mu \mathrm{m}$. Sporophytes unknown in North America.

Distribution and habitat.-Specimens of Plagiothecium angusticella in North America have been seen only in eastern North America. This species is recorded so far only from the U.S.A. (Connecticut, and West Virginia) (Fig. 6). In these localities, it grows mainly in epigeic (in mixed conifer-hardwood forests, on extensive rock outcrops, in humid mixed hardwoodhemlock forests with acidic rock outcrops along rivers) and epilithic habitats (in calcareous seepage in vertical rock face; see Appendix 1).

Plagiothecium succulentum (Wilson) Lindb., Botaniska Notiser 43: 143. 1865. 1865. Hypnum denticulatum var. succulentum Wilson, Bryologia Britanicae 407. 1855. Type: Wilson Winwck Stone Quarry, near Warrington; J. Nowell near Todmorden.

Plagiothecium sylvaticum var. succulentum (Wilson) Spruce, Journal of Botany, British and Foreign 18: 357. 1880.

Plagiothecium denticulatum var. succulentum (Wilson) Dixon, The Student's Handbook of British Mosses. 437. 1896. 

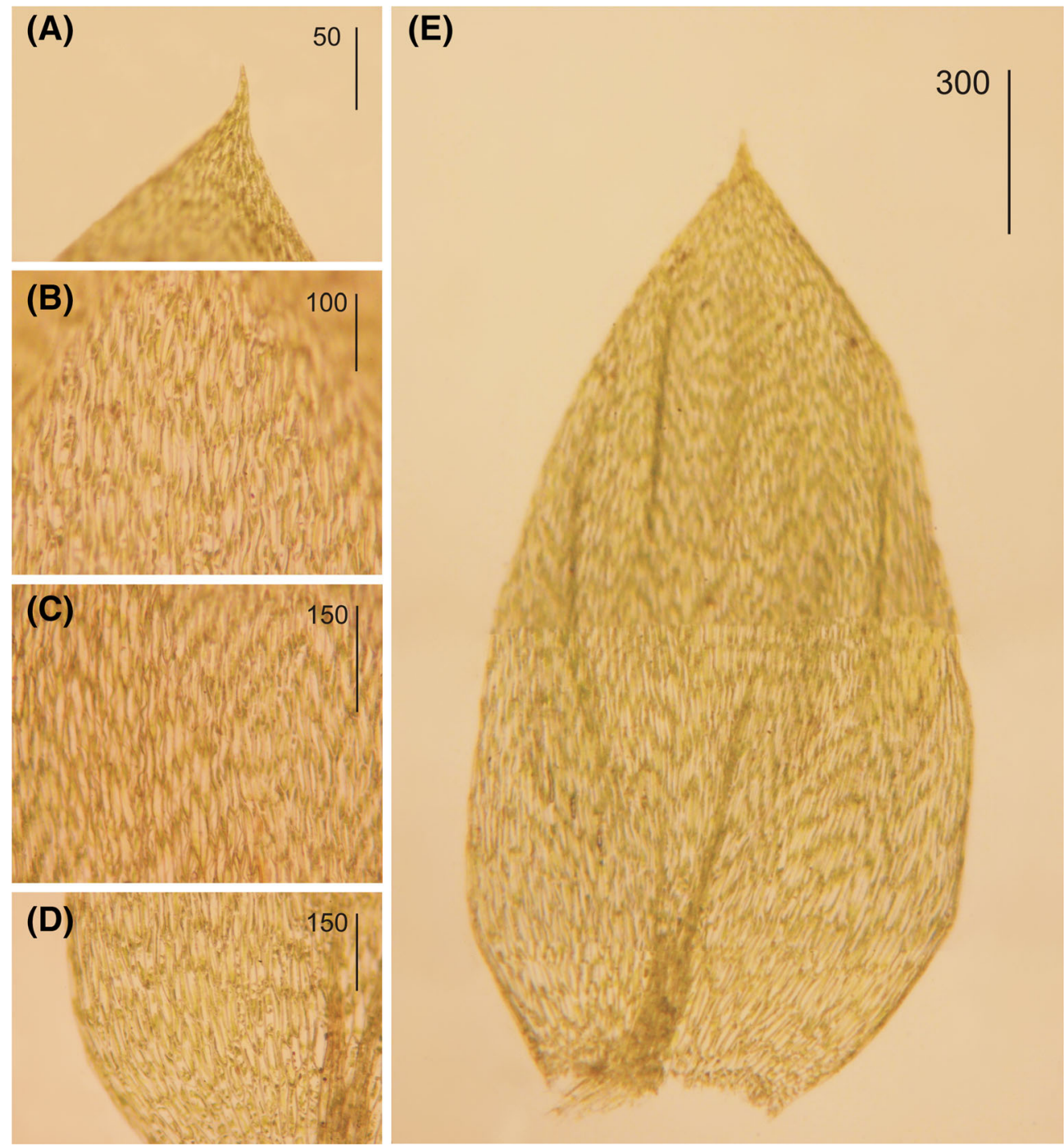

Fig. 3. Plagiothecium angusticellum specimens from North America (from B. Goffinet, 11,795, NY 02331429). A. Leaf apex. B-D. Cells exhibiting shape and dimensions from three different leaf zones. B. Distal zone. C. Mid zone. D. Basal zone. E. Stem leaf of the examined species. (Scale in $\mu \mathrm{m}$.)

Plagiothecium sylvaticum ssp. succulentum (Wilson) Amann \& Meyl., Flore des Mousses de la Suisse 1: 174. 1919.

Plants medium-sized to large, usually yellowish to yellowish-green or golden green, very glossy. Stems to $3 \mathrm{~cm}$ long, complanate-foliate, in cross-section rounded, with a diameter of 220 $351 \mu \mathrm{m}$, central strand developed, epidermal cells 4.7-8.7 × 5.2-14.9 $\mu \mathrm{m}$, parenchyma thin-walled, 12.6-31.4 × 7.4-36.5 $\mu \mathrm{m}$; leaves spreading, in dry condition not shrunken, complanate, symmetrical, ovate-lanceolate (Fig. 4), at the middle of the stem $2.46-3.08 \times 0.82-1.38 \mathrm{~mm}$, those near the stem apex much smaller, tapering to a narrow acuminate, entire apex; costae 2 , extending to half of leaf length, reaching $0.70-1.36 \mathrm{~mm}$; laminal cells linear-rhomboidal, linear-hexagonal, overlapping, not in transverse rows, their size depends on the location on the leaf, the longest in the middle part of leaf, the widest at the base, apical cells $68.3-197 \times 7.8-17.5 \mu \mathrm{m}$, those at mid-leaf $132.5-245.5 \times 10.2-17.9 \mu \mathrm{m}$, those 

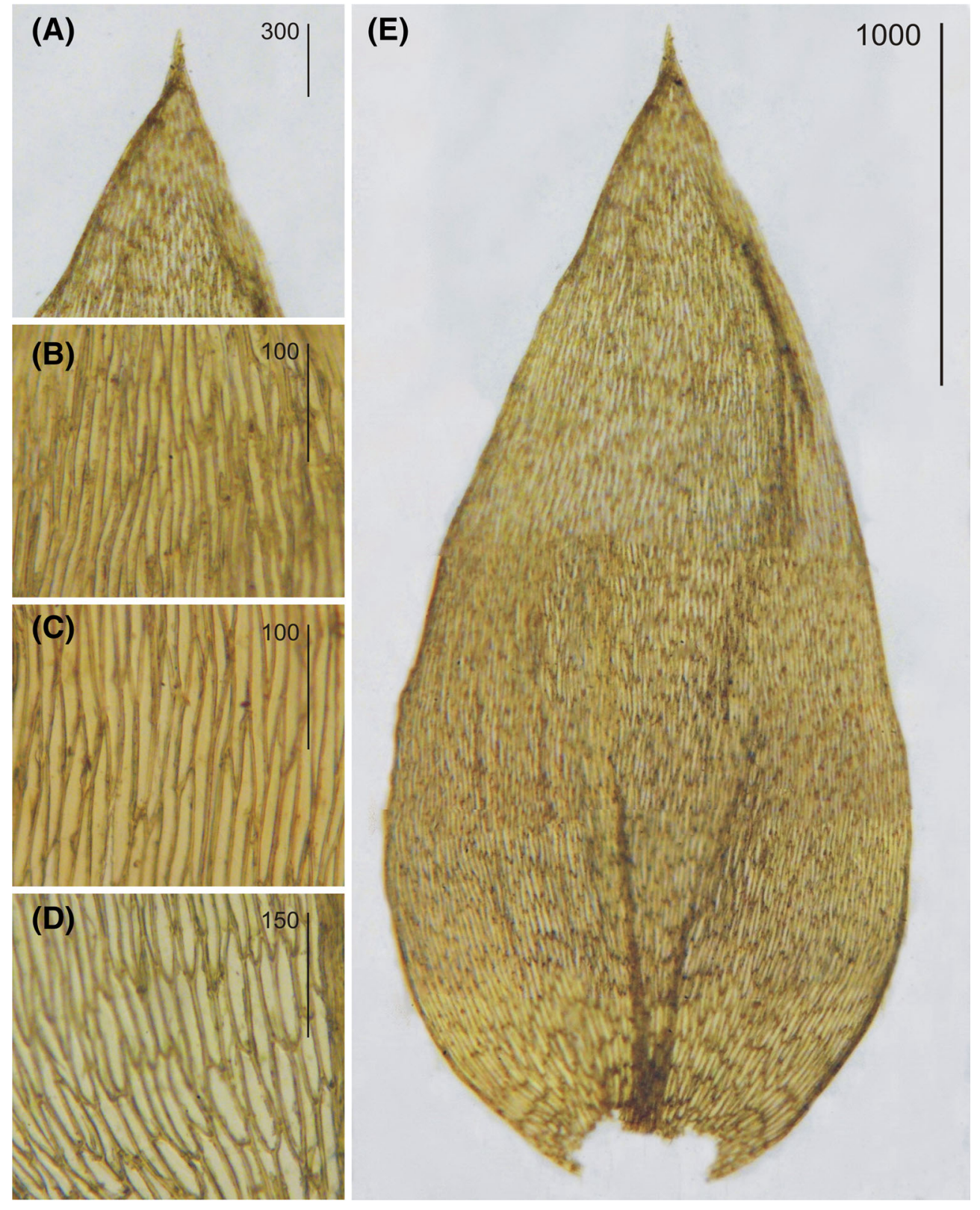

Fig. 4. Plagiothecium succulentum specimens from North America (from W. R. Buck, 32,700, NY 00481218). A. Leaf apex. B-D. Cells exhibiting shape and dimensions from three different leaf zones. B. Distal zone. C. Mid zone. D. Basal zone. E. Stem leaf of the examined species. (Scale in $\mu \mathrm{m}$.)

toward the insertion $82.9-194.4 \times 10.9-28 \mu \mathrm{m}$ (Fig. 4); cells of decurrencies in 2-3 rows, rectangular to quadrate, $22.3-58.9 \times 10.4-20.1 \mu \mathrm{m}$. Sporophytes unknown in North America.

Distribution and habitat.-Plagiothecium succulentum in North America is distributed only in eastern North America. This species in noted from Canada (Labrador, Ontario, Quebec) and the U.S.A. (Connecticut, Georgia, Maryland, Massachusetts, New Hampshire, New York, North Carolina, Ohio, Pennsylvania, Tennessee, Vermont, Virginia, West Virginia, Wisconsin) (Fig. 6). In 
these localities, it grows mainly in epilithic habitats (on wet rocks, dripping sandstone ledges in the deep shade under hemlocks, moist shady rocks, vertical rocks near falls, moist ledges, and in cool, damp and shaded lower parts of cliffs), less often in epiphytic (on tree roots), epigeic (on wet, springy humus) and epixylic habitats (decayed wood). In these habitats, this species was listed in dense woods; mixed hardwoods, wet cliffs (cool damp shaded lower parts of cliffs), next to falls; in spruce-fir forests with Rhododendron and Sorbus, deep wooded ravines, and on mountainsides; see Appendix 1.

\section{Plagiothecium succulentum f. propaguliferum}

E. Bauer, Deutsche Botanische Monatsschrift 20: 2. 1902. Type. Bryotheca Bohemica, No. 259, an Erlenstöcken in Erlbruche am Schiessniger Teiche bei B. Leipa, Bohemia, Czech Republic V. Schiffner, (Isotype: C 9395!).

Plants small to medium-sized, dark golden to brown, very glossy. Stems to $2-2.5 \mathrm{~cm}$ long, complanate-foliate, in cross-section rounded, with a diameter of 367-534 $\mu \mathrm{m}$, central strand developed, epidermal cells 10.4-25.4 × 18.8-35.2 $\mu \mathrm{m}$, parenchyma thin-walled, $24.2-52.8 \times 23.4$ $58 \mu \mathrm{m}$; leaves spreading, in dry condition shrunken, complanate, symmetrical, ovate-lanceolate (Fig. 5); at the middle of the stem 3.20-3.60× $1.40-1.53 \mathrm{~mm}$, those near the stem apex much smaller, tapering to a narrow acuminate, entire apex; costae 2, extending to half of leaf length, reaching $0.76-1 \mathrm{~mm}$; laminal cells linear-rhomboidal, linear-hexagonal, overlapping, not in transverse rows, their size depends on the location on the leaf, the longest in the middle part of the leaf, the widest at the base, apical cells 162.2 $252.1 \times 17-21.7 \mu \mathrm{m}$, those at mid-leaf 176.6 $264.5 \times 17.7-19.6 \mu \mathrm{m}$, those toward the insertion 168-273.5 × 27.6-35.8 $\mu \mathrm{m}$ (Fig. 5); decurrencies of 2-3 rows of rectangular cells, $25-63.9 \times 14.5-$ $25.6 \mu \mathrm{m}$. Sporophytes unknown in North America.

Distribution and habitat.-During this research, specimens of Plagiothecium succulentum f. propaguliferum were noted only from one locality in eastern North America (U.S.A., Vermont) (Fig. 6), where it occurs in epilithic habitats (in damp crevices in the shade of cliffs; see Appendix 1).

\section{Discussion}

Species of Plagiothecium sect. Orthophyllum are frequently misidentified in herbaria and the literature, and representatives of the section are often considered to be taxonomically problematic (Nyholm, 1965; Iwatsuki, 1970; Lewinsky, 1974; Smith, 2001; Wolski, 2017, 2018). However, many of these challenges are the result of a lack of basic taxonomic research to document intraspecific variability in problematic taxa (Wynns et al., 2017; Ignatova et al., 2019; Wolski, Nowicka-Krawczyk, 2020). Moreover, many of the taxa of the section can be distinguished in both Euasia and North America on the basis of easily recognizable features (Grout, 1932; Sharp, 1939; Greene, 1957; Nyholm, 1965).

Plagiothecium sylvaticum (at present a synonym of $P$. nemorale) among representatives of the genus Plagiothecium was described as a species with leaves more or less shrunken in dry condition (Grout, 1932; Sharp, 1939). This is a very important taxonomic feature that helps distinguish, among others, $P$. nemorale from other species of the genus (Green, 1957; Nyholm, 1965; Iwatsuki, 1970; Smith, 2001, Wolski \& NowicakaKrawczyk, 2020).

Within North America, all five of the documented taxa of section Orthophyllum occur in eastern North America, with a distinct dominance of $P$. succulentum, but in the Pacific Northwest only P. longisetum occurs. In comparison with the Eurasian material of $P$. nemorale, $P$. longisetum and $P$. angusticellum (Wolski, Nowicka-Krawczyk, 2020), the North American material of these species tends to have lower values for the analyzed quantitative features. Despite this, values of the most taxonomically significant features the length and width of leaf cells - are relatively similar to the average values in the Eurasian populations.

The specimens cited in this study were previously identified as either $P$. denticulatum or $P$. cavifolium. The easiest way to distinguish the species treated here from $P$. denticulatum is by the symmetry of the leaves and form of decurrent cells. Plagiothecium denticulatum is characterized by very clearly asymmetric leaves (most leaves rounded asymmetric) and decurrent cells that are rounded, inflated and 

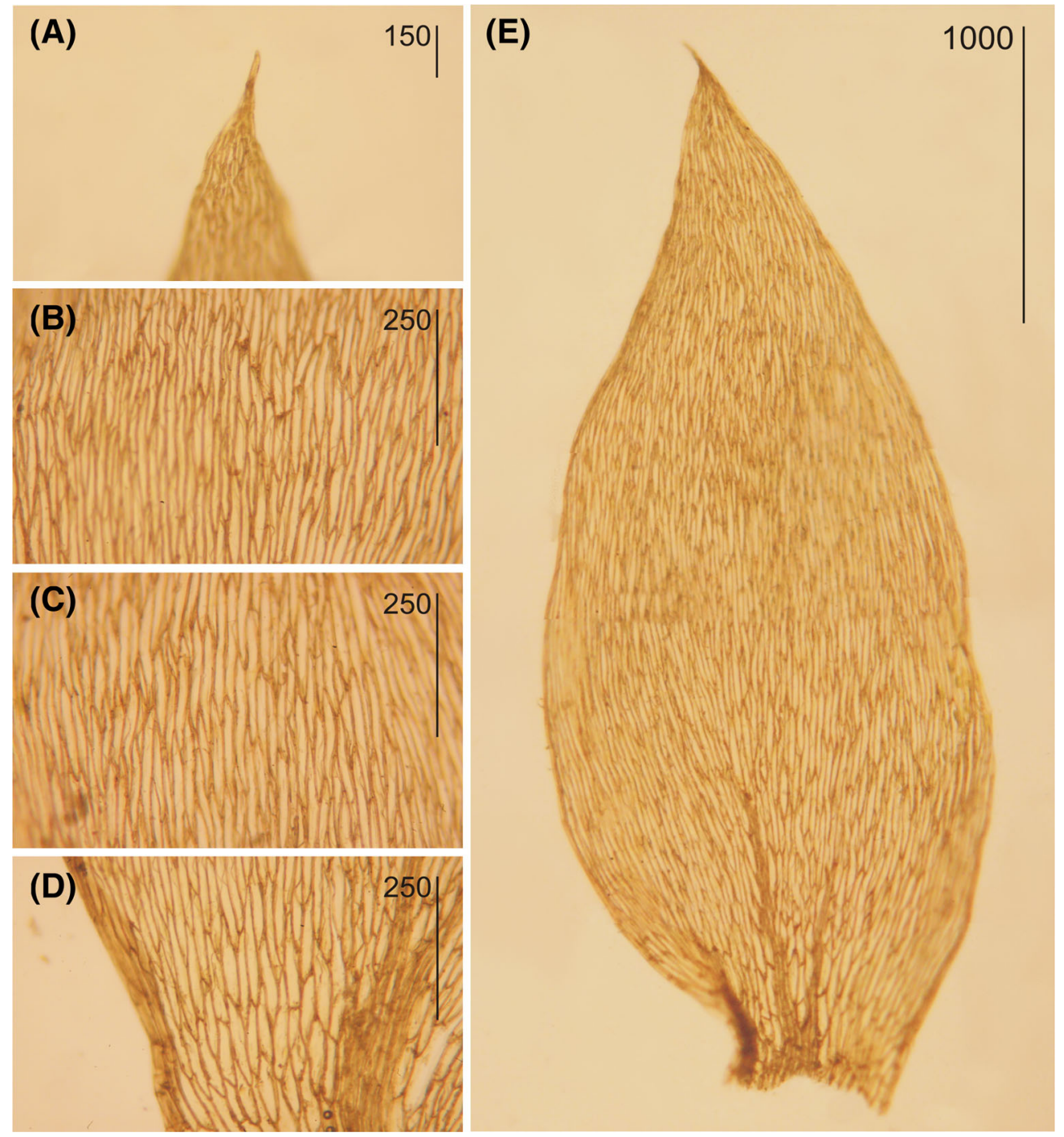

Fig. 5. Plagiothecium succulentum f. propaguliferum specimens from North America (from A. J. Grout, NY 00506521). A. Leaf apex. B-D. Cells exhibiting shape and dimensions from three different leaf zones. B. Distal zone. C. Mid zone. D. Basal zone. E. Stem leaf of the examined species. (Scale in $\mu \mathrm{m}$.)

form distinct auricles (best viewed in situ on the stem). Plagiothecium nemorale and $P$. succulentum (including $P$. succulentum $\mathrm{f}$. propaguliferum) have symmetric leaves, while $P$. longisetum and $P$. angusticellum have asymmetric or slightly asymmetric leaves. However, in all four of these species, the shape of decurrent cells is rectangular or quadrate, not inflated, and they do not form distinct auricles (Green, 1957; Nyholm, 1965; Iwatsuki, 1970; Lewinsky, 1974; Smith, 2001; Wolski, 2017, 2018; Wolski, Nowicka-Krawczyk, 2020).
The best features to distinguish the species treated here from $P$. cavifolium are the arrangement of leaves on the stem, leaf symmetry, and cell shape dimensions (Fig. 7). Plagiothecium cavifolium has julaceous, imbricate, symmetric leaves and long and narrow (76-144 × 10$16 \mu \mathrm{m})$, slightly asymmetric cells. In contrast, the species treated here have complanately arranged, symmetric and asymmetric leaves. Cells at mid-leaf are short and wide (50-90 $\times$ 17-20 $\mu \mathrm{m})$ and symmetric in $P$. nemorale; long and wide $(100-130 \times 17-20 \mu \mathrm{m})$ in 


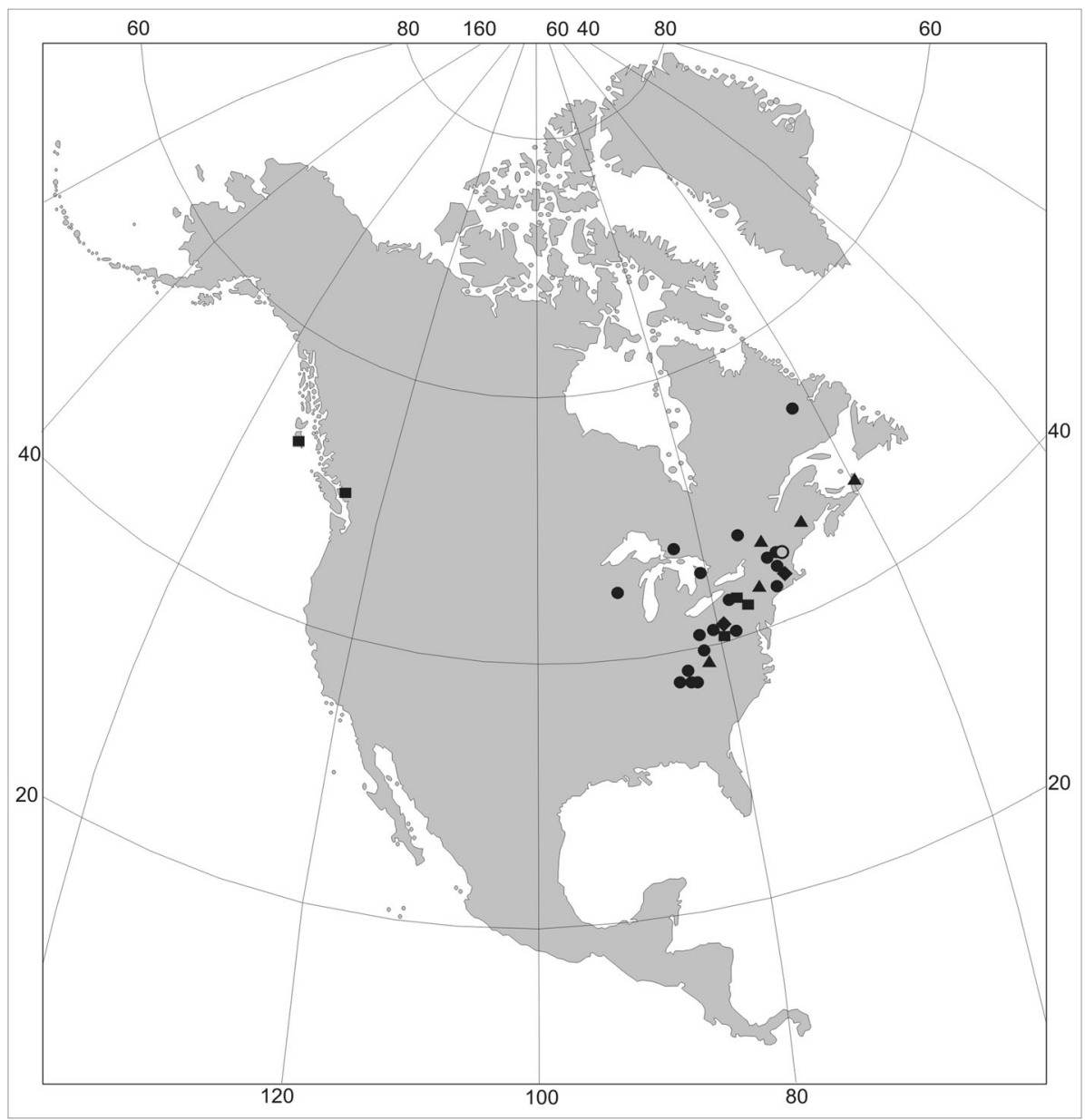

- P. succulentum, ○ P. succulentum f. propaguliferum, ^ P. nemorale,

- P. longisetum, $\quad P$. angusticellum.

Fig. 6. Distribution of the examined taxa of Plagiothecium sect. Orthophyllum in North America.

P. longisetum; long and narrow $(90-120 \times 12.5-$ $17.5 \mu \mathrm{m})$ and slightly asymmetric in $P$. angusticellum; very long and narrow (132.5$245.5 \times 10.2-17.9 \mu \mathrm{m})$ and slightly asymmetric in P. succulentum; and very long and wide (176.6-264.5 × 17.7-19.6 $\mu \mathrm{m})$ and slightly asymmetric in $P$. succulentum f. propaguliferum (Green, 1957; Nyholm, 1965; Iwatsuki, 1970; Lewinsky, 1974; Smith, 2001; Wolski, 2017, 2018; Wolski, Nowicka-Krawczyk, 2020).

Other species that could be confused with those treated here are $P$. japonicum and $P$. fallax Cardot \& Thér. The first is known from North America only from Alaska and was treated by Iwatsuki (1970) as a form of
P. nemorale - P. nemorale $f$. japonicum (Sak.) Iwats., but is now considered a separate species (Wynns 2015). Plagiothecium japonicum is quite similar to $P$. nemorale, but has larger, broadly ovate, concave leaves, with an acuminate apex, larger costae, and rigid, dilated cells; it is quite easy to distinguish from other species. Genetic analysis indicates that $P$. japonicum may be a hybrid or an allopolyploid of $P$. cavifolium and $P$. nemorale (Wynns 2015), although this requires further research. Plagiothecium fallax is also known in North America from Alaska, but has a broad distribution in Japan. It is similar to some of the treated species due to 

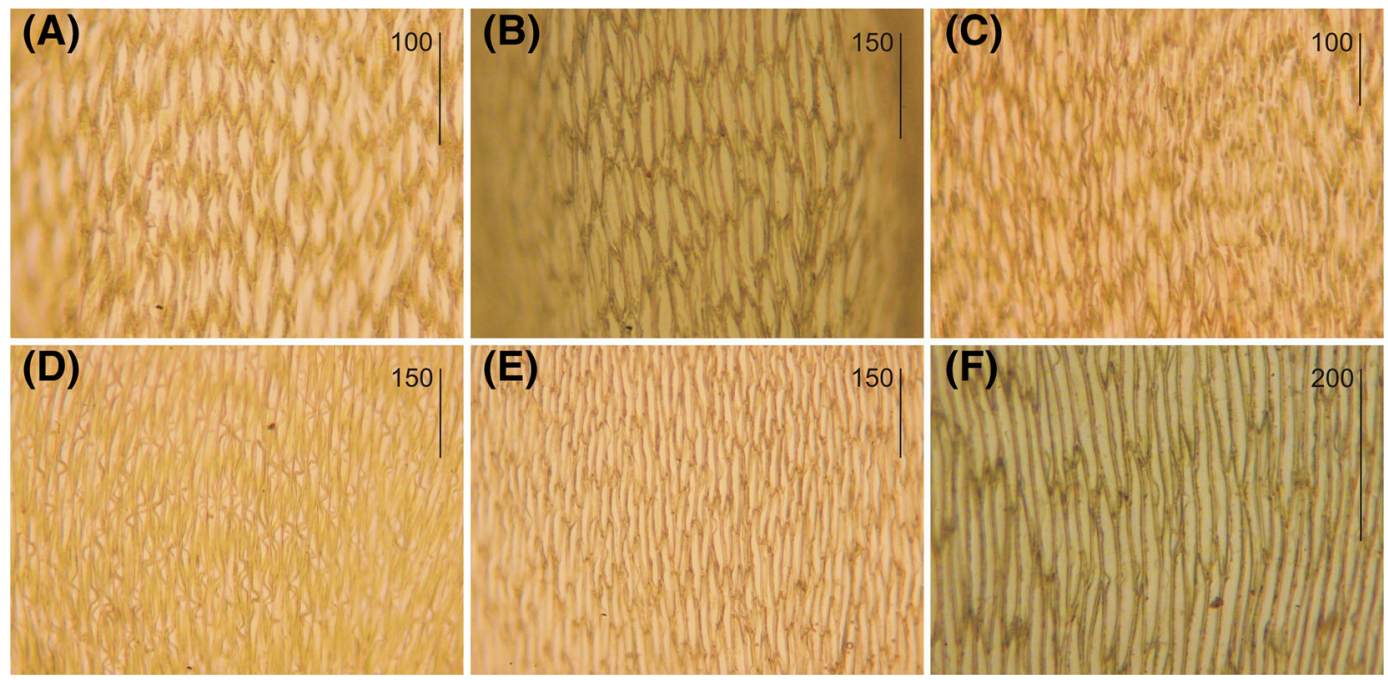

Fig. 7. Comparison of cells from the central part of the leaf in six species of Plagiothecium, exhibiting interspecific differences in cell dimensions and shape. A. P. nemorale (R. Düll, 855, NY 00506577). B. P. longisetum (W. B. Schofield, 31,629, NY 00163472). C. P. angusticellum (B. Goffinet, 11,795, NY 02331429). D. P. denticulatum (F. J. Herman, 18,234, NY 00506531). E. P. cavifolium (P. M. Patterson, 2914, NY 506587). F. P. succulentum (W. R. Buck, 32,700, NY 00481218).

its broadly ovate-lanceolate, asymmetric leaves, and rather open areolation of the cells. It resembles a smaller, less undulate version of P. undulatum (Hedw.) Schimp. with very small alar decurrencies, and as indicated by Wynns (2015), is relatively easy to distinguish from other representatives of Plagiothecium.

\section{Key to the taxa of Plagiothecium sect. Orthophyllum from North America and other taxa commonly confused with them}

1. Leaves asymmetric (mostly rounded asymmetric); decurrenct cells rounded; inflated; forming distinct auricles; the apex of the

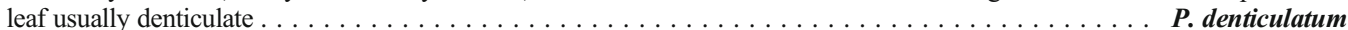

1. Leaves symmetric or asymmetric; decurrent cells usually rectangular; not forming distinct auricles; the apex denticulate or not.

2. Leaves symmetric; cells at mid-leaf short $(50-90 \times 17-20 \mu \mathrm{m})$; narrowly hexagonal or elongate hexagonal; in transverse

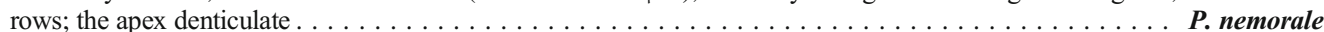

2. Leaves symmetric or asymmetric; cells longer than $100 \mu \mathrm{m}$; linear-rhomboidal, linear-hexagonal; straight to slightly fexuose; in transverse rows or not; the apex not denticulate.

3. Leaves asymmetric.

4. Plant yellowish-green; without metallic luster; leaves in dry condition shrunken; concave; asymmetric; ovate; the apex straight, not denticulate; cells long and wide; elongate hexagonal; 100-125 × 17-20 $\mu \mathrm{m}$ at mid-leaf; in transverse rows. . . P. longisetum

4. Plant green; without metallic luster; most leaves complanate; concave; asymmetric; not shrunken in dry condition; the apex slightly curved; acuminate; not denticulate; cells along and wide $(90-137.5 \times 17.5-20)$; slightly asymmetric $\boldsymbol{P}$. angusticellum

3. Leaves symmetric.

5. In dry condition leaves shrunken $\ldots \ldots \ldots \ldots \ldots \ldots \ldots \ldots \ldots \ldots$. succulentum $\mathbf{f}$. propaguliferum

5. In dry condition leaves not shrunken.

6. Plants light green to yellowish; leaves on the stem julaceous; imbricate and concave; symmetric; cells long and narrow $(76-144 \times 10-16 \mu \mathrm{m})$; forming transverse rows; slightly flexuose. . . . . . . . . P. cavifolium

6. Plants yellowish to golden green; very glossy; leaves symmetric; ovate-lanceolate; cells linear-rhomboidal or linearhexagonal; long and wide $(132.5-245.5 \times 10.2-18 \mu \mathrm{m})$; not forming transverse rows . . . . . . P. succulentum

\section{Acknowledgments}

I thank very much the curators and employees of the herbaria cited (NY, FH, F) for the loan of specimens and William R. Buck (Institute of
Systematic Botany, The New York Botanical Garden) for his helpful comments, suggestions and corrections of the text, as well as the manuscript reviewers. 


\section{Literature cited}

Anderson, J. E., S. Cooper-Ellis \& B. C. Tan. 1997. New distribution notes on the mosses of Massachusetts. Rhodora 900: 352-367.

Anderson, L. E., H. A. Crum \& W. R. Buck. 1990. List of the mosses of North America north of Mexico. The Bryologist 93: 448-499.

Andrews, A. L. 1921. Further bryophytes from North Carolina (and Tennessee). The Bryologist 24: 49-58.

Brotherus, V. F. 1909. Musci (Laubmoose) III. Unterklasse Bryales: II. Gruppe: Pleurocarpi. Pp. 701-1172 in: Engler, A. \& Prantl, K. (eds.), Die natürlichen Pflanzenfamilien 1(3.2). Leipzig: Verlag von Wilhelm Engelmann.

Buck, W. R., \& Ireland, R. R. 1989. Plagiotheciaceae. Flora Neotropica 50. New York: The New York Botanical Garden.

Clebsch, A. 1954. Interesting bryophytes from Tennessee. Castanea 19: 1-20.

Crum, H., W. C. Steere \& L. E. Anderson. 1965. A list of the mosses of North America. The Bryologist 68: 377-432.

Crum, H., W. C. Steere \& L. E. Anderson. 1973. A new list of mosses of North America north of Mexico. The Bryologist 76: 85-130.

Dierßen, K. 2001. Distribution, ecological amplitude and phytosociological characterization of European bryophytes. Bryophyt. Bibl., 56: 1-289.

Fleischer, M. 1912. Laubmoose. Nov. Guinea Résultats l'expédition Sci. Néerlandaise à La Nouv. En 1907 1909, 8: 735-753.

Gier, L. J. 1949. Bryophytes of Kansas. Transactions of the Kansas Academy of Science 52: 58-65.

Githens, T. S. 1957. Additional mosses of central and eastern Pennsylvania. The Bryologist 60: 20-23.

Greene, S. W. 1957. The British species of the Plagiothecium denticulatum-P.silvaticum group. Transactions of the British Bryological Society 3: 181-190.

Grout, A. J. 1932. Moss Flora of North America North of Mexico, Vol. 3, part 3. Published by the author, Newfane, Vermont.

Grout, A. J. 1939. Mosses of Mount Washington. The Bryologist 43: 36-38.

Grout, A. J. 1940. List of mosses of North America north of Mexico. The Bryologist 43: 17-131.

Hill, M. O., N. Bell, M. A. Bruggeman-Nannenga, M. Brugués, M. J. Cano, J. Enroth, K. I. Flatberg, J.-P. Frahm, M. T. Gallego, R. Garilleti, J. Guerra, L. Hedenäs, D. T. Holyoak, J. Hyvönen, M. S. Ignatov, F. Lara, V. Mazimpaka, J. Muñoz, \& L. Söderström. 2006. An annotated checklist of the mosses of Europe and Macaronesia. Journal of Bryology 28: 198-267.

Ignatov, M. S., O. M. Afonina \& E. A. Ignatova. 2006. Check-list of mosses of East Europe and North Asia. Arctoa 15: 1-130.

Ignatova, E. A., A. V. Fedorova, O. I. Kuznetsova, M. S. Ignatov. 2019. Taxonomy of the Plagiothecium laetum complex (Plagiotheciaceae. Bryophyta) in Russia. Arctoa 28: 28-45.

Ireland, R. R. 1969. A taxonomic revision of the genus Plagiothecium for North America, north of Mexico. National Museum of Natural Sciences Publication in Botany The National Museum of Canada, Ottawa, Canada 1: 1118.
Ireland, R. R. 1985. The genus Plagiothecium in North America. Evansia 2: 4-9.

Ireland, R. R. 1986. Synopsis of the genus Plagiothecium in North America. Lindbergia 12: 49-56.

Ireland, R. R., G. R. Brassard, W. B. Schofield \& D. H. Vitt. 1987. Checklist of the mosses of Canada II. Lindbergia 13: 1-62.

Iwatsuki, Z. 1970. A revision of Plagiothecium and its related genera from Japan and her adjacent areas, I. Journal Hattori Botanical Laboratory 33: 331-380.

Jedlička, J. 1948. Monographia specierum Europaerum gen. Plagiothecium s.s. (Partis specialis I. Sumarium). Spisy Vydávané Přirodovědeckou Fakultou Masarykovy University Publ. Fac. Sci. Univ. Masaryk 308: 1-45.

Lewinsky, J. 1974. The family Plagiotheciaceae in Denmark. Lindbergia 2: 185-217.

Macoun, J. \& N. C. Kindberg. 1892. Catalogue of Canadian Plants. Part VI - Musci. Geological and Natural History Survey of Canada. William Forest Brown \& Co., Montreal.

Macoun, J. 1889. Contributions to the bryology of Canada. Bulletin of the Torrey Botanical Club 16: 91-98.

Norris, D. H. 1967. Bryophytes of Cumberland Falls State Park, Kentucky. Castanea 32: 159-171.

Nyholm, E. 1965. Illustrated Moss Flora of Fennoscandia. II. Musci. Fasc. 5. C.W.K. Gleerup, Lund.

Ochyra, R., Smith, R. L. \& Bednarek-Ochyra, H. 2008. Plagiotheciaceae. Pp. 570-577 in: Illustrated Moss Flora of Antarctica. Cambridge: Cambridge University Press.

Pedersen, N. \& Hedenäs, L. 2001. Phylogenetic relationships within the Plagiotheciaceae. Lindbergia, 26: 62-76.

Pedersen, N. \& Hedenäs, L. 2002. Phylogeny of the Plagiotheciaceae based on molecular and morphological evidence. Bryologist, 105(3): 310-324.

Renauld, F. \& J. Cardot. 1892. Musci Americae septentrionalis ex operibus novissimis recensiti et methodice dispositi. Revue Bryologique 19: 1-61.

Ros, M. R., V. Mazimpaka, U. Abou-Salama, M. Aleffi, T. Blockeel, M. Brugués, R. M. Cros, M. D. Dia, G. M. Dirkse, I. Draper, W. El-Saadawi, A. Erdağ, A. Ganeva, R. Gabriel, J. M. González-Mancebo, C. Granger, I. Herrnstadt, V. Hugonnot, K. Khalil, H. Kürschner, A. Loasda-Lima, L. Luís, S. Mifsud, M. Privitera, M. Puglisi, M. Sabovljević, C. Sérgio, H. M. Shabbara, M. Sim-Sim, A. Sotiaux, R. Tacchi, A. Vanderpoorten \& O. Werner. 2013. Mosses of the Mediterranean, an annotated checklist. Cryptogamie Bryologie 34: 99-283.

Sharp, A. J. 1939. Taxonomic and ecological studies of eastern Tennessee bryophytes. The American Midland Naturalist 21: 267-234.

Smith, A. J. E. 2001. The Moss Flora of Britain and Ireland. Cambridge University Press, Cambridge, U.K.

Sullivant, W. S. \& L. Lesquereux. 1865. Musci BorealiAmericani quorum specimina exsiccata. Edito secunda, Columbi Ohioensium, Sumptibus Auctorum.

Suzuki, T. A. 2016. Revised new catalog of the mosses of Japan. Hattoria 7: 9-223.

Thomas, R. 1952. Bryophytes from the Iliamna Lake region, Alaska. The Bryologist 55: 287-289.

Wolski, G. J. 2017. Morphological and anatomical variability of Plagiothecium nemorale in central Poland. Herzogia, 30: $36-50$. 
Wolski, G. J. 2018. Are Plagiothecium cavifolium.P. nemorale and $P$. succulentum indeed variable species? Pakistan Journal of Botany 50: 1579-1589.

Wolski, G. J., P. Nowicka-Krawczyk. 2020. Resurrection of the Plagiothecium longisetum Lindb. and proposal of the new species $-P$. angusticellum. PLoS ONE 15(3): e0230237

Worley, I. A. \& Z. Iwatsuki. 1970. A checklist of the mosses of Alaska. The Bryologist 73: 59--71.

Wynns J. T. 2015. Molecular phylogeny and systematic revision of the pleurocarpous moss genus Plagiothecium. Ph.D. thesis, University of Copenhagen, Copenhagen.

Wynns, J. T. \& Lange, C. B. A. 2014. A comparison of 16 DNA regions for use as phylogenetic markers in the pleurocarpous moss genus Plagiothecium (hypnales). American Journal of Botany 101(4): 652-669. https://doi. org/10.3732/ajb.1300269

Wynns, J. T. \& Schröck, C. 2018. Range extensions for the rare moss Plagiothecium handelii, and its transfer to the resurrected genus Ortholimnobium. Lindbergia 41(1). https://doi.org/10.25227/linbg.01087

Wynns, J. T., K. R. Munk \& C. B. A. Lange. 2017. Molecular phylogeny of Plagiothecium and similar hypnalean mosses with a revised sectional classification of Plagiothecium. Cladistics 37(5): 469-501.

APPENDIX 1. Additional specimens examined.

Plagiothecium nemorale. CANADA. Nova Scotia: Inverness County, Cape Breton Highlands National Park, along the Acadian Trail, near Cheticamp Campgound, northeast of Inverness, $46^{\circ} 38^{\prime} \mathrm{N}, 61^{\circ} 01^{\prime} \mathrm{W}, 22 \mathrm{Jul} 1968, R$. R. Ireland 12085 (NY 00163469).

U.S.A. Maine: Canton, 23 Aug 1934, J. C. Parlin s.n. (NY 00481248). New York: Cattaraugus County, Allegany State Park, around "Thunder Rock" in deciduous forest primitive rock, on rocks (shady), elev. 720 m., 22 May 1981, R. Düll 855 (NY 00506577); Ulster County, town of Shandaken, Catskill Forest Preserve, Slide Mountain Wilderness Area, W slope of Slide Mountain, along the trail from the parking area $\mathrm{W}$ of NY $47,42^{\circ} 00^{\prime} 28^{\prime \prime} \mathrm{N}, 74^{\circ} 25^{\prime} 13^{\prime \prime} \mathrm{W}$, elev. $300 \mathrm{~m}$., northern hardwoods, 13 Sep 2008, W. R. Buck 54032 (NY 01077084). North Carolina: McDowell County, on the moist, diffusely lit base of a tree in the Fagus forest on the crest of the mountain at Craggy Gardens north of Marion, elev. 1600 m., 1 Jul 1983, D. H. Norris 68,967 (NY 00588089).

Plagiothecium longisetum. CANADA. British Columbia: Queen Charlotte Is., W. Moresby Id., N side of Gowgaia Bay, seepy humus of bank, 13 Jul 1966, W. B. Schofield 31629 (NY 00163472); Vancouver, Lynn Creek Canyon, on the floor of Rubus spectabilis thicket, 20 Feb 1978, W. B. Schofield \& G. Godfrey 67662 (NY 00159540).
U.S.A. Pennsylvania: Pocono Mts., Buck Hill Falls, near the Inn, 9 May 1947, H. S. Blair s.n. (NY 00481490); McKean County, rocks on moist shaded sandstone, 12 Mar 1897, Burnett 601 (NY 00481207). Virginia: Botetourt County, on boulder in shade, 22 Jun 1959, P. M. Patterson 2914 (NY 00506587).

Plagiothecium angusticellum. U.S.A. Connecticut: Windham County, town of Westford, Yale Myers Forest, Boston Hollow, along Boston Hollow Road, between Eastford Road and Barlow Road, mixed conifer-hardwood forest with extensive rock outcrops, 19 Sep 2009, W. R. Buck 55530 (NY 01136516). West Virginia: Tucker County, Monongahela National Forest, Dolly Sods Wilderness, Red Creek trail, humid mixed hardwood-hemlock forest with acidic rock outcrops along the river, in calcareous seeping in a vertical rockface, $38^{\circ} 58^{\prime} 22^{\prime \prime} \mathrm{N}, 7^{\circ} 23^{\prime} 51^{\prime \prime} \mathrm{W}$, elev. 800 m., 04 Jul 2014, B. Goffinet 11795 (NY 02331429).

Plagiothecium succulentum. CANADA. Labrador: A. C. Waghorne s.n. (NY 00163504). Ontario: Agloma District, 1.3 miles north of Agawa River on Rt. 17 on east side of road in rocky cliffs and valleys, conifers in lower part and maples in area on top of hill, 31 May 1958, C. M. Wetmore 1148 (NY 00164186); 01 Jul 1935 (NY 00164187); Owen Sound, West Hill, on tree roots in woods, 1 Jul 1935, E. A. Moxley s.n. (NY 00163508, FH 848924). Quebec: Luskville Falls, northeast of Luskville, $45^{\circ} 38^{\prime} \mathrm{N}, 76^{\circ} 00^{\prime} \mathrm{W}, 6$ Jul 1969, R. R. Ireland \& L. Ley 10022 (NY 00163481).

U.S.A. Deep wooded ravines, on the mountains of New Jersey, New York, and New England (NY 00506571). Connecticut: East Haven County, 22 Jun 1879, J. A. Allen 473483 (NY 00481062). Georgia: Rabun County, Chattahoochee National Forest, Rabun Bald, $34^{\circ} 58^{\prime} \mathrm{N}, 83^{\circ} 18^{\prime} \mathrm{W}$, elev. 1115-1420 m., mixed hardwoods with gneissic cliffs, 04 Oct 1997, W. R. Buck 32700 (NY 00481218, NY 00506524). Maryland: Garrett County, dripping sandstone ledge in the deep shade under hemlocks, the bank of the Youghiogheny River below Swallow Falls, 8 miles NNW, elev. 2400, 30 Aug 1958, F. J. Hermann 14,889 (NY 004734911). Massachusetts: Barre, J. W. Grosvenor s.n. (F C1058822F). New Hampshire: White Mts., Oakes s.n. (NY 00506573). New York: Dec 1867, C. F. Austin s.n. (NY 00506565, NY 00505535); Sand Lake (NY 00481214); 17 Jun 1874, Watkins s.n. (NY 00481215). North Carolina: Macon County, Falls, on Cullasaja River NW of Highlands, in moist shady rocks next to falls, elev. 3500 ft., 12 Aug 1977, M. L. Hicks 6823 (NY 02682709); Jackson County, vicinity of Woodfin Cascades, Woodfin Mountain, $3 \mathrm{~km}$ NW of Balsam Gap, vertical rocks near falls, elev. $1280-1310 \mathrm{~m}$., $35^{\circ} 26^{\prime} \mathrm{N}, 83^{\circ} 06^{\prime} \mathrm{W}, 06$ May 1990, P. L. Redfearn \& A. Redfearn 36273 (NY 
1596884); Mitchell County, Pisgah National Forest, Roan Mt. Gardens, spruce-fir forest with Rhododendron and Sorbus, elev. ca. 1920 m., $36^{\circ} 06^{\prime} \mathrm{N}, 82^{\circ} 08^{\prime} \mathrm{W}, 24$ Sep 1993, W. R. Buck 24062 (NY 00481196). Ohio: Jackson County, on a wet rock, 03 May 1936, Bartley \& Pontius 153 (NY 00506545). Pennsylvania: McKean County, Bradford, 04 Aug 1894, D. A. Burnett s.n. (FH 00848908). Tennessee: Sevier County, above Rocky Spur, Rainbow Falls trail to Mt. Le Conte, Great Smoky Mountains National Park, 28 Jul 1959, W. B. Schofield 10698 (NY 00506604, F C1058792F). Vermont: Newfane, downers Glen, Monchester, 03 Aug 1939, I. M. Haring s.n. (NY 00481051); decayed wood and humus, moist ledges, Baker Brook ravine, elev. 1600 m., 16 Aug 1903, 23 Jul 1921, A. J. Grout s.n. (NY 00481053, NY 00506594), elev. 1600 m., A. J. Grout s.n. (F C1058849F), decayed wood and humus, elev. 1600 ft., 23 Jul 1921 (NY 00506522), moist ledges, 18 Jul 1921 (NY 00481055), 16 Aug 1903 (NY
00481056). Virginia: Smyth County, on wet, springy humus at the base of a small cliff, $09 \mathrm{Jul}$ 1956, P. M. Patterson \& R. M. Schuster 2755 (NY 00506584); May-Jun 1892, A. M. Vail \& E. G. Britton s.n. (NY 00481173, NY 00481174). West Virginia: Pocahontas County, Monongahela National Forest, vicinity of Island Camp along Greenbriar River $38^{\circ} 34^{\prime} 46^{\prime \prime} \mathrm{N}$, $79^{\circ} 42^{\prime} 17^{\prime \prime} \mathrm{W}$, on moist rock, 6 May 1976, W. R. Buck B940 (NY 01105252); 08 Jun 1934, C. M. Roberts s.n. (NY 00481180). Wisconsin: Richland County, $0.5 \mathrm{mi}$. N of Lloyd, NE-facing Cambrian sandstone cliffs along Willow Creek, cool damp shaded lower parts of cliffs, 30 Jun 1974, M. Nee 12,478 (NY 00481231); 1869, C. F. Austin s.n. (NY 00481076, FH 848917).

Plagiothecium succulentum f. propaguliferum. U.S.A. Vermont: Mansfield Mt., 8 Aug 1906, A. J. Grout s.n. (NY 00506521). 